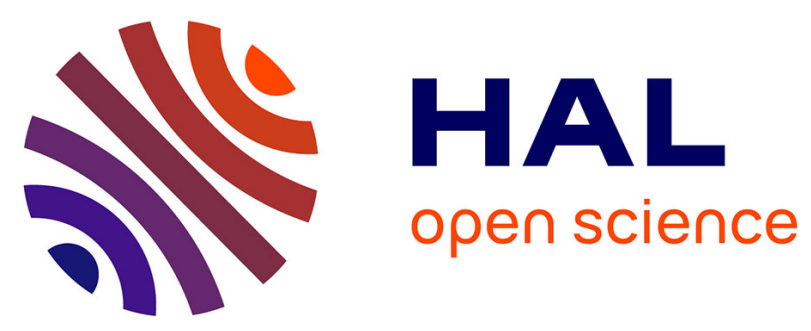

\title{
Estimation of surface fluxes in a small agricultural area using the three-dimensional atmospheric model meso-NH and remote sensing data
}

Dominique Courault, Pierre Lacarrere, Philippe Clastre, Patrice

Lecharpentier, Frédéric Jacob, Olivier Marloie, Laurent Prevot, Albert Olioso

\section{To cite this version:}

Dominique Courault, Pierre Lacarrere, Philippe Clastre, Patrice Lecharpentier, Frédéric Jacob, et al.. Estimation of surface fluxes in a small agricultural area using the three-dimensional atmospheric model meso-NH and remote sensing data. Canadian Journal of Remote Sensing, 2003, 29 (6), pp.741-754. 10.5589/m03-044 . hal-02675988

\section{HAL Id: hal-02675988 \\ https://hal.inrae.fr/hal-02675988}

Submitted on 6 Nov 2021

HAL is a multi-disciplinary open access archive for the deposit and dissemination of scientific research documents, whether they are published or not. The documents may come from teaching and research institutions in France or abroad, or from public or private research centers.
L'archive ouverte pluridisciplinaire HAL, est destinée au dépôt et à la diffusion de documents scientifiques de niveau recherche, publiés ou non, émanant des établissements d'enseignement et de recherche français ou étrangers, des laboratoires publics ou privés.

$$
\text { Copyright }
$$


Estimation of surface fluxes in a small agricultural area using the three-dimensional atmospheric model Meso-NH and remote sensing data

Dominique Courault, Pierre Lacarrère, Philippe Clastre, Patrice Lecharpentier, Frédéric Jacob, Olivier Marloie, Laurent Prévot, and Albert Olioso

D. Courault,1 P. Clastre, P. Lecharpentier, O. Marloie, L. Prévot, and A. Olioso. Unité Climat Sol Environnement, Institut national de recherche agronomique (INRA), domaine St Paul, site Agroparc, 84914 Avignon, France.

P. Lacarrère. Centre national de recherches météorologiques (CNRM), avenue Coriolis, 31000 Toulouse, France.

F. Jacob. École supérieure d'Agriculture de PURPAN, 75, voie du TOEC, 31076 Toulouse, France.

1Corresponding author (e-mail: courault@avignon.inra.fr). 


\begin{abstract}
.
To provide an accurate water budget over a whole basin, hydrological models need to know the spatial variability of evapotranspiration at the watershed scale. The three-dimensional (3D) atmospheric models can provide such estimations at a regional scale, since they calculate the different energy and water fluxes by accounting for the landscape heterogeneity with a mesh grid varying from a few metres to several kilometres. We have used such a transfer model (Meso- $\mathrm{NH}$ ) at a high spatial scale $(50 \mathrm{~m})$ to simulate the small agricultural region of the Alpilles ( $4 \mathrm{~km} \sim 5 \mathrm{~km}$ ), where an experiment took place in 1997 and included intense ground measurements on different types of crops and airborne and satellite data collection. It was the first time that this model was used at such a fine resolution. The aim of this paper is to analyze the effects of the various crops on the spatial variability of the main energy fluxes, particularly evapotranspiration. We also wished to validate Meso-NH from this important available dataset. All input parameters were derived from remote sensing or airborne data: leaf area index ( $\mathrm{LAl}$ ) and albedo were computed from polarization and directionality of the earth's reflectances (POLDER) images. Roughness length was estimated combining both a land-use map obtained from Satellite pour l'Observation de la Terre (SPOT) images and the POLDER images. Maps of the main energy fluxes and temperatures were simulated for two periods in April and June and showed large spatial variations because of differences in soil moisture and in roughness of the crop types. Comparisons between the simulations and the measurements gave satisfactory results. Thermal images acquired by the infrared airborne camera were in good agreement with the surface temperatures estimated by the model. Significant differences were observed when we compared, on the same area, the value of averaged fluxes with the value of fluxes calculated with averaged surface parameters. This was due to the nonlinearity processes associated with averaging of environmental variables. The interest in using a mesoscale model applied at microscale is that coherent structures can be observed in the surface boundary layer, particularly on transects of the vertical wind speed. Such structures cannot be simulated at a larger scale or analyzed with simplified models. Remote sensing data acquired at a fine spatial resolution are a useful tool to provide accurate surface parameters to such a model. This allows quantification of the effect of each crop type on the spatial variation of temperature and evapotranspiration and thus improves our knowledge of the water budget of an agricultural landscape and the watershed functioning.
\end{abstract}




\section{Résumé.}

L'estimation de la variation spatiale de l'évapotranspiration à l'échelle d'un bassin versant est primordiale si l'on veut obtenir des bilans précis sur les échanges d'eau et d'énergie avec des modèles hydrologiques. Les modèles $3 \mathrm{D}$ simulant les transferts atmosphériques peuvent fournir des informations sur cette variation spatiale à des échelles régionales, car ils calculent les différents flux de surface, en tenant compte de l'hétérogénéité du paysage, simulé suivant des grilles qui peuvent varier de quelques centaines de mètres à plusieurs kilomètres. Nous avons utilisé un tel modèle, Meso-NH, afin d'étudier quel est l'impact des cultures sur les variations spatiales des flux et du climat à l'échelle d'une petite région agricole : la zone du projet ALPILLES/ReSeda ( $4 \mathrm{~km} \sim 5 \mathrm{~km}$ au sud-est d'Avignon). En 1997, une expérimentation importante a eu lieu sur ce site avec de nombreuses mesures caractérisant le sol, la végétation et l'atmosphère, accompagnées d'images de divers capteurs satellitaires et aéroportés. Les principaux paramètres de surface intervenant pour l'estimation des flux d'énergie ont été dérivés à partir de ces données de télédétection. L'indice foliaire (LAI), la fraction de trous et l'albédo ont été obtenus à partir d'images POLDER. Des cartes de rugosité ont été élaborées en combinant des information SPOT et POLDER. Des simulations courtes ont permis d'obtenir des cartes des principaux flux d'énergie et des températures de l'air et de la surface à deux périodes en avril et en juin. La comparaison des simulations aux mesures donne des résultats globalement satisfaisants. Le modèle reproduit correctement le comportement des principales cultures qui présentent une variabilité importante des flux même sur une petite zone. Les températures de surface simulées par le modèle sont également bien reproduites et comparables aux images thermiques acquises sur le site pendant la période étudiée. En revanche, la comparaison des flux et des températures obtenus lorsque l'on considère une zone homogène (de $5 \mathrm{~km} \sim 5 \mathrm{~km}$ ) caractérisée par la moyenne des principaux paramètres de surface, à ceux obtenus sur la zone hétérogène d'Alpilles, montre des écarts importants de plus de $50 \mathrm{~W} / \mathrm{m} 2$ pour le rayonnement net et de $2^{\circ}$ pour la température. Ceci est dû à la non-linéarisation des équations utilisées pour décrire ces échanges. L'intérêt d'utiliser un modèle complexe $3^{D}$ à fine échelle apporte des informations sur les processus de turbulence qui se passent en surface. On peut voir apparaître des structures cohérentes dans la couche limite de surface (notamment sur les transects verticaux de vitesse verticale) qui ne peuvent être analysées qu'avec ce type de modèle. D'autres simulations pour différentes conditions atmosphériques et de surface sont nécessaires afin d'approfondir l'étude de ces structures et analyser les problèmes liés aux changements d'échelle. Néanmoins, il ressort que les données de télédétection acquises à haute résolution apportent des informations utiles à de tels modèles en leur permettant d'accéder à une caractérisation plus fine de la surface améliorant ainsi l'estimation des flux transmis à l'atmosphère. 


\section{Introduction}

At the scale of a small agricultural region (smaller than $50 \mathrm{~km} \sim 50 \mathrm{~km}$ ), the landscape is characterized by different types of heterogeneities depending on soil moisture or crop roughness that induce significant variations in both surface fluxes and meteorological conditions. Many studies have analyzed the influence of vegetation on the generation and modification of mesoscale circulation (Segal et al., 1988; Pielke, 2001). The effect of irrigation on large regions has been studied extensively (Barnston and Schickeldanz, 1984; Segal et al., 1998; De Ridder and Gallée, 1998). These studies show that an increase in convective precipitation can sometimes be related to a decrease in air temperature induced by irrigation. The mesoscale models used in these studies (two- or three-dimensional versions) allow analysis of these situations, taking into account all interactions between soil, plants, and the atmosphere. Until now, however, most of the work devoted to the effect of the vegetation cover on atmospheric circulation considered a mesh grid ranging from 3 to 1 $\mathrm{km}$. The spatial resolution remains too coarse to be useful for agronomical applications. At the present time, the trend is to account for surface processes with greater and greater accuracy to realistically reproduce meteorological events and climatological patterns. By providing more realistic lower boundary conditions, land surface schemes can help to improve the numerical simulation of the atmosphere. Among the most developed models, Mesoscale Non Hydrostatique (Meso-NH) can simulate surface fluxes from a regional to a semi continental scale. With increasing satellite imagery resolution, identification of smaller areas with a well-pronounced contrast is a straightforward task.

The purpose of the present study was to evaluate the effect of the vegetation cover on the local meteorological conditions (fluxes and temperatures) at the scale of a small agricultural region ( $4 \mathrm{~km} \sim 5 \mathrm{~km}$, grid mesh of $50 \mathrm{~m}$ ) using the Meso- $\mathrm{NH}$ model. The interest in working at such a spatial resolution was to better describe the different types of crops and their interactions with the atmosphere. If we want to improve our knowledge of the water budget of agricultural landscapes for crop monitoring and water management, it is necessary to identify the different types of crops according to their development stage and water status, which is why a fine resolution was chosen. The spatial variability of surface fluxes over a small region can be obtained using easier models (one-dimensional approach by juxtaposition; Lagouarde and Brunet, 1991) combined with remote sensing data (like the SEBAL model; Bastiaanssen et al., 1998; Jacob, 1999). Most of these models, however, consider the lateral exchanges between the crops negligible and are built on debatable simplified assumptions (e.g., estimation of roughness length). The use of a three-dimensional (3D) atmospheric model allows taking into account all exchanges between the soil, plant, and atmosphere (vertical and lateral transfers), simulating the evolution of the planetary boundary layer, and all associated climatic variables. On the other hand, the complexity of these models makes them difficult to use and expensive, particularly in terms of computing time, so only short simulations can be performed at high spatial resolution.

The aim of our study therefore was to evaluate the contribution of a fine description of the different surfaces compared with a regional approach consisting of averaging the surface parameters over the whole area. There are two important aspects of this study: (i) the spatial variability, which must be analyzed at the local scale (for crop monitoring); and (ii) the operational application, which needs a temporal scale according to the crop cycle or a watershed scale for a regional response. The originality of this work deals with the 
combination of these two aspects, that is, using a $3^{D}$ mesoscale model applied at a microscale with (for the first time) a very fine spatial resolution to describe the different crops.

Short simulations have been done for different atmospheric conditions and developing vegetation states to take into account the temporal evolution. We chose to simulate the area of the Alpilles Remote Sensing Data Assimilation (ReSeDA) experiment (Olioso et al., 2002), since many measurements were available to initialise and validate the model. This area is located $30 \mathrm{~km}$ southeast of Avignon, France, and is very flat. Moreover, the region was characterized by a large variety of crops. Most of the field range in size from 2 to 8 ha. Many satellites or airborne sensors have acquired data with a high spatial resolution $(20 \mathrm{~m})$, useful for describing the different surfaces and providing more accurate parameters for the model.

In a first part of the paper, the Meso-NH model is briefly described, detailing the Interaction Soil Biosphere Atmosphere (ISBA) surface scheme to understand how the different crops are differentiated. Then we present the study area and the main data used with the model. Lastly, the results from the model are discussed in comparison with the measured data.

\section{Short description of the Meso-NH model}

The Meso-NH model is the new nonhydrostatic mesoscale atmospheric model of the French research community. It has been jointly developed by the Aerology Laboratory and the Centre national de recherches météorologiques (CNRM), Toulouse. The model is intended to be applicable at large (synoptic) to small (large eddy) scales and is coupled with an on-line atmospheric chemistry module. A detailed description can be found on the Web at the following address, at which different reports on the scientific documentation are available: http://www.aero.obs.fr/ mesonh/.

The radiative scheme is from the European Canter for Medium Range Weather Forecasts (ECMWF) and calculates the radiative fluxes, taking into account absorption-emission of long-wave radiation and reflection, scattering, and absorption of solar radiation by the earth's atmosphere and surfaces.

The surface and the atmosphere interact via energy fluxes applied at the base of the atmospheric numerical model. The fluxes provided to the atmospheric model are the momentum flux, the turbulent sensible and latent heat fluxes, the upward radiative fluxes, and, as an option, the $\mathrm{CO}_{2}$ flux. Surface fields such as albedo and emissivity have direct effects on the surface and atmosphere radiation balance. The determination of these twodimensional (2D) surface fields appears therefore to be particularly crucial and difficult. See the section "Implementation of Meso-NH to simulate the Alpilles area" for a description on how these fields were obtained.

\section{ISBA surface scheme}

The land surface parameterisation scheme used in Meso-NH is the ISBA model described in Noilhan and Mahfouf (1996). The scheme describes the exchanges of heat and water between the low-level atmosphere, the vegetation, and the soil. There are five prognostic 
equations for deep temperature (T2), deep soil water content (w2), surface temperature (Ts), surface soil water content (wg), and interception water storage (wr):

$$
\begin{aligned}
& \frac{\partial w_{\mathrm{g}}}{\partial t}=\frac{C_{1}}{\rho_{\mathrm{w}} d_{1}}\left(P_{\mathrm{g}}-E_{\mathrm{g}}\right)-\frac{C_{2}}{\tau}\left(w_{\mathrm{g}}-w_{\mathrm{geq}}\right) \\
& \frac{\partial T_{\mathrm{s}}}{\partial t}=C_{\mathrm{T}}\left(R_{\mathrm{n}}-H-L E\right)-\frac{2 \pi}{\tau}\left(T_{\mathrm{S}}-T_{2}\right) \\
& \frac{\partial w_{\mathrm{r}}}{\partial t}=\operatorname{veg} P-\left(E_{\mathrm{v}}-E_{\mathrm{tr}}\right)-R_{\mathrm{r}} \\
& \frac{\partial T_{2}}{\partial t}=\frac{1}{\tau}\left(T_{\mathrm{s}}-T_{2}\right) \\
& \frac{\partial w_{2}}{\partial t}=\frac{1}{\rho_{\mathrm{w}} d_{2}}\left(P_{\mathrm{g}}-E_{\mathrm{g}}-E_{\mathrm{tr}}\right)-\frac{C_{3}}{d_{2} \tau} \max \left(0,\left(w_{2}-w_{\mathrm{fc}}\right)\right)
\end{aligned}
$$

where $t$ is the time; $C_{1}$ and $C_{2}$ are the force restore coefficients for soil moisture; $\rho w$ is the density of liquid water; $\mathrm{d}_{1}$ is the depth of the first soil level; $\mathrm{Pg}$ is the precipitation at the ground surface; $\mathrm{Eg}$ is the surface evaporation from bare soil; $\tau$ is a time constant of 1 day; wgeq is the soil water content at the capillarity-gravity equilibrium; CT is the heat capacity of the surface soil; $\mathrm{Rn}$ is the net radiation; $\mathrm{H}$ is the sensible heat flux; $\mathrm{LE}$ is the latent heat flux, where $L$ is the specific heat of vaporization, and $E$ is the total evapotranspiration; veg is the fraction of vegetation cover; $P$ is the precipitation at the screen; Ev and Etr are the evapotranspiration and transpiration, respectively, from the vegetation; and $\mathrm{Rr}$ is the runoff. Only one energy balance is considered for the whole ground-vegetation system. The net radiation at the surface is the sum of the absorbed fractions of the incoming solar radiation $(\mathrm{Rg})$ and the atmospheric infrared radiation $(\mathrm{Ra})$, reduced by the emitted infrared radiation:

$$
R_{\mathrm{n}}=R_{\mathrm{g}}(1-a)+\varepsilon\left(R_{\mathrm{a}}-\sigma T_{\mathrm{s}}^{4}\right)=H+L E+G
$$

where $a$ is the albedo; $\varepsilon$ is the emissivity; $\sigma$ is the Stefan-Boltzmann constant; and $G$ is the ground heat flux, which is the residual of the energy balance. The value of $G$ is employed in the Deardorff (1978) equation to compute surface temperature, weighted by a thermal coefficient (CT) including a vegetation term Cv (vegetation heat capacity) and veg. The turbulent fluxes are calculated using the classical aerodynamic formulas. For the sensible heat flux,

$$
H=\rho c_{\mathrm{p}} C_{\mathrm{H}} V_{\mathrm{a}}\left(T_{\mathrm{s}}-T_{\mathrm{a}}\right)
$$

where $\mathrm{cp}$ is the specific heat; $\rho, \mathrm{Va}$, and Ta are, respectively, the air density, wind speed, and air temperature at the lowest atmospheric level; and $\mathrm{CH}$ is the drag coefficient depending on the thermal stability of the atmosphere. The water vapor flux $E$ is the sum of the evaporation of liquid water from both the soil surface (i.e., Eg) and the vegetation (i.e., Ev): 


$$
\begin{aligned}
& L E=L E_{\mathrm{g}}+L E_{\mathrm{v}} \\
& E_{\mathrm{v}}=\operatorname{veg} \rho a C_{\mathrm{H}} h_{\mathrm{v}}\left[q_{\mathrm{sat}}\left(T_{\mathrm{s}}\right)-q_{\mathrm{a}}\right]
\end{aligned}
$$

where $L$ is the specific heat of vaporization, qsat(Ts) is the saturated specific humidity at the temperature Ts, and qa is the atmospheric specific humidity at the lowest atmospheric level. The exchange coefficient (hv) depends on the surface resistance (rs) and aerodynamical resistance (ra):

$$
h_{\mathrm{v}}=(1-\delta) \frac{r_{\mathrm{s}}}{r_{\mathrm{s}}+r_{\mathrm{a}}}+\delta
$$

If Ev is negative, dew occurs at the potential rate and then $h v=1$. Following Deardorff(1978), $\delta$ is a power function of the moisture content of the interception reservoir. The aerodynamic resistance is $\mathrm{ra}=(\mathrm{CHVa})-1$. The surface resistance $\mathrm{rs}$ depends on both atmospheric factors and available water in the soil following the Jarvis approach:

$$
r_{\mathrm{s}}=\frac{r_{\mathrm{smin}}}{F_{1} F_{2} F_{3} F_{4} \mathrm{LAI}}
$$

where the different factors $\mathrm{F}_{1}, \mathrm{~F}_{2}, \mathrm{~F}_{3}$, and $\mathrm{F}_{4}$ are described in Jacquemin and Noilhan (1990). Some parameters depend on the vegetation types. The leaf area index ( $\mathrm{LAI}$ ) corresponds to the leaf surface per unit of soil surface. The main surface parameters involved in the flux calculations are albedo (a), emissivity $(\varepsilon)$, momentum length (zo), thermal roughness length (zoh), displacement height, veg, and LAl. Soils parameters are computed from soil texture (Manzi, 1993).

\section{The Alpilles dataset}

The Alpilles experiment was conducted in 1996 in the southeast of France as part of the Alpilles ReSeDa program and was spread over 1 year until completion in 1997. It aimed at providing a substantial dataset for assessing crop and soil processes from remote sensing data to propose methods to estimate net primary production, evapotranspiration, and yield of cultivated crops (Prévot et al., 1999). The site had an area of $4 \mathrm{~km} \sim 5 \mathrm{~km}$ and was very flat, with elevations of around $10 \mathrm{~m}$ above sea level. The main crops were wheat, maize, sunflower, and grassland, with minor crops of tomatoes, artichokes, and alfalfa. The average field size was around $200 \mathrm{~m} \sim 200 \mathrm{~m}$. The different ground data collected over the site are described in detail by Olioso et al. (2002). Remote sensing data were collected at various wavelength ranges and at different spatial resolutions using spaceborne sensors (NOAA, thematic mapper (TM), Satellite pour l'Observation de la Terre (SPOT), ERS, RADARSAT) and airborne sensors (POLDER, an INFRAMETRICS 760 thermal infrared (TIR) camera, ERASME (airborne multiangle scatterometer)). Micrometeorological measurements were performed on seven fields with the objective of a continuous monitoring of surface energy balance components. The main characteristics of the vegetation (LAI, height, biomass) and 
the soil (temperature, moisture, roughness) were measured. Radiosoundings were also acquired over the site every $2 \mathrm{~h}$ for two periods in April and June 1997.

\section{Implementation of Meso-NH to simulate the Alpilles area}

\section{Configuration: initial conditions}

We used the model in PREP_IDEAL mode (in the Meso-NH language this means that grid nesting was not defined and nudging was not used to force atmospheric input with data from a larger climate model like ARPEGE (French Forecast Meteorological Model)). We represented the whole of the Alpilles area using a box of $100 \sim 100$ horizontal meshes of 50 $m$ resolution and 31 vertical meshes with levels going from the surface to $4000 \mathrm{~m}$ (the first level is at $4 \mathrm{~m}$ above the ground). The boundary conditions were cyclic, and the initialization was made with a radiosounding measured over the site at $10 \mathrm{~h}$.

We set constant values for the soil moisture $(w g 1, w g 2)$ and deep temperature $\left(T_{2}\right)$ over the whole area when initialising the model. These values corresponded to averaged measurements around $10 \mathrm{~h}$. All input data corresponded to real data measured over the area.

Table 1 gives a summary of these initial conditions and the configurations defined to perform simulations with Meso-NH.

Table 1. Summary of the initial conditions defined for Meso-NH simulations.

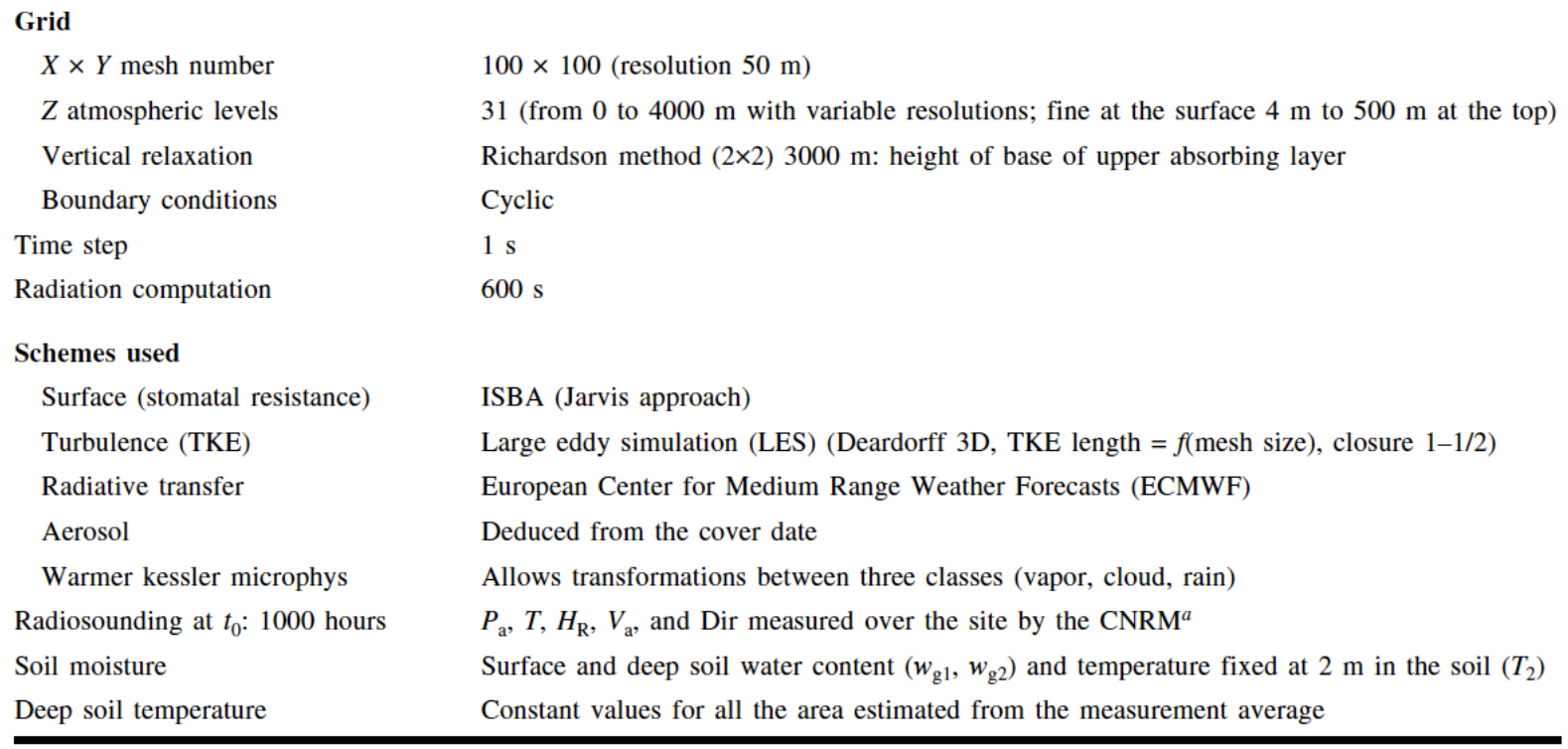

${ }^{a}$ Dir, wind direction; $H_{\mathrm{R}}$, relative humidity; $P_{\mathrm{a}}$, air pressure; $T$, temperature; $V_{\mathrm{a}}$, horizontal wind speed.

\section{The input parameters}

The first step consisted in interpolating the different maps of the main surface parameters from remote sensing acquired at a higher resolution ( $20 \mathrm{~m}$ ) according to the Meso-NH format defined at $50 \mathrm{~m}$. 
- From POLDER airborne data: LAl, veg, and albedo

Albedo, LAl, and vegetation fraction (veg) parameters were derived from the multiangular POLDER images (Jacob et al., 2002a; 2002b). The first stage consists of computing hemispherical and nadir reflectances at $443 \mathrm{~nm}$ (blue), $550 \mathrm{~nm}$ (green), $670 \mathrm{~nm}$ (red), and 865 $\mathrm{nm}$ (near infrared) by inverting the Walthall kernel-driven model (Walthall et al., 1985) over the POLDER multiangular dataset (Jacob, 1999). Next, LAI and veg were calculated by feeding a neural network (NN) with nadir and hemispherical reflectances estimated in the POLDER channels. The NN was previously calibrated over a database simulated with the radiative transfer model (SAIL model; Verhoef, 1984) for a wide variety of crops and LAI values (Weiss et al., 2002).

Visible and near-infrared albedos ( $\alpha$ vis and $\alpha$ nir, respectively) were calculated as a linear combination of POLDER hemispherical reflectances ( $\rho$-blue, $\rho$-green, $\rho$-red, $\rho$-nir-red) using coefficient sets proposed by Liang et al. (1999):

$$
\begin{aligned}
& \alpha_{\text {vis }}=0.3511 \rho_{\text {blue }}+0.3923 \rho_{\text {green }}+0.2603 \rho_{\text {red }}-0.003 \\
& \alpha_{\text {nir }}=0.6088 \rho_{\text {nir-red }}+0.1442
\end{aligned}
$$

- From SPOT images and land-use map

The other surface parameters such as emissivity, minimum stomatal resistance (rsmin), root zone depth ( $\left.\mathrm{d}_{2}\right)$, roughness lengths (zoveg and zovegh), and parameters linked to the stomatal resistance $(\gamma, \mathrm{rgl})$ took constant values according to the vegetation type of the landuse map. The land-use map was obtained from a supervised classification of SPOT images (Figure 1). It was either a mean value obtained from the ground measurements or a value found in the literature. 


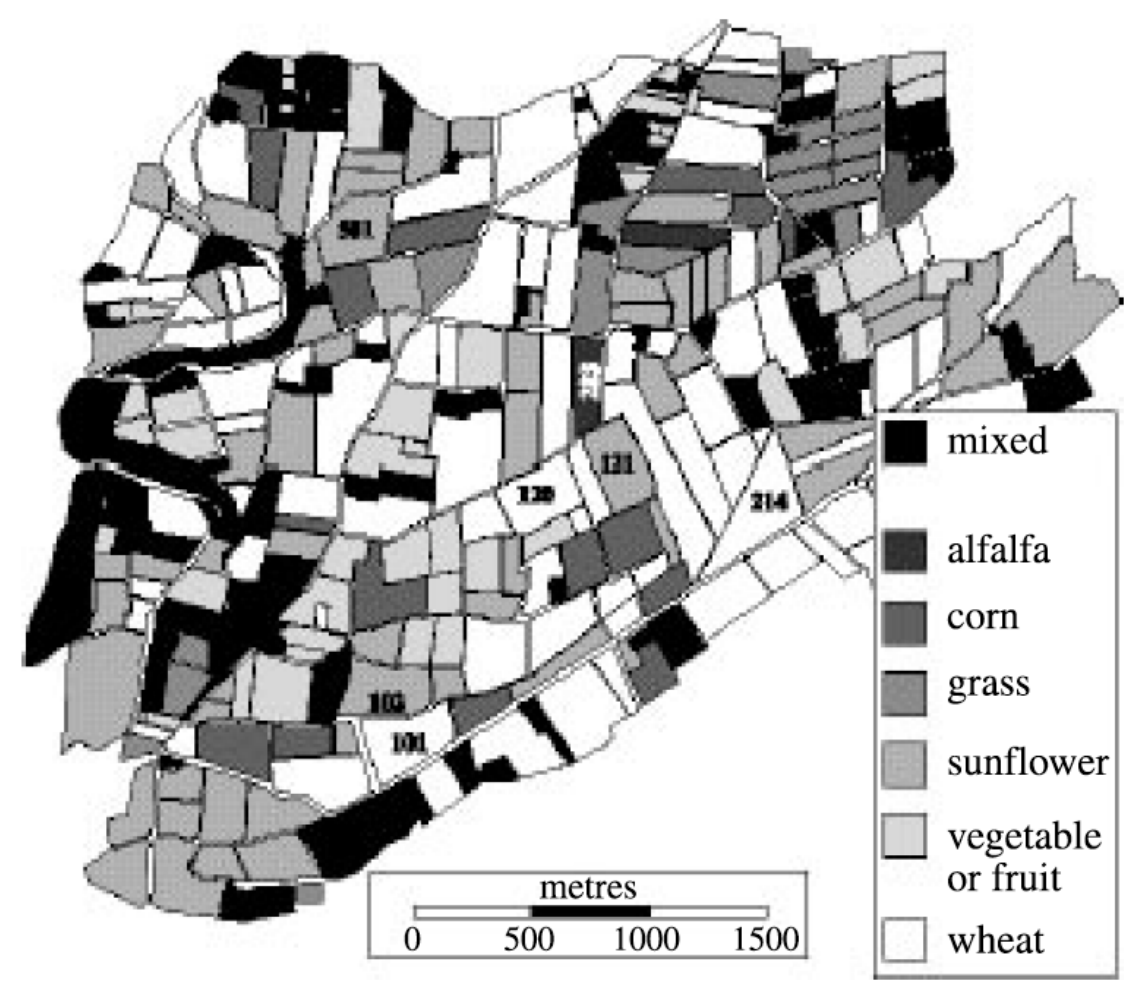

Figure 1. Land-use map obtained from a supervised classification using four SPOT images. Energy balance measurements were done on the numbered fields (101, 102, 120, 121, 203, 214, and 501).

Roughness lengths were estimated using the following common relationships:

$$
\begin{aligned}
& z_{\text {Oveg }}=0.13 h \\
& z_{\text {0vegh }}=0.1 z_{0}
\end{aligned}
$$

where $\mathrm{h}$ is the crop height. For the wheat class, we had to introduce a spatial variation in roughness, since we observed a great variation for this crop (Figure 2a). These variations were due to different factors: different sowing dates and cultural practices. Indeed, most of the sowing dates were in November, although some were in spring (for example, field 214). Moreover, about $10 \%$ of the fields were irrigated (field 120). We tried to find a relationship between wheat height and vegetation indices computed from remote sensing data. Different indices such as NDVI, SAVI, and TSAVI (Baret and Guyot, 1991) were computed from POLDER images and compared with the height measurements (or with height interpolation between the measurements). The best result was obtained with the TSAVI index computed for the period from the beginning of the crop cycle until the middle of April. The relationship was found to be linear, with a significant correlation coefficient (Figure $2 b$ ). Lastly, the calibrated relationship we obtained for wheat height (in $\mathrm{cm}$ ) was as follows:

$$
z_{0 \mathrm{veg}(\text { wheat })}=0.013(70.6 \times \mathrm{TSAVI}+3.84)
$$




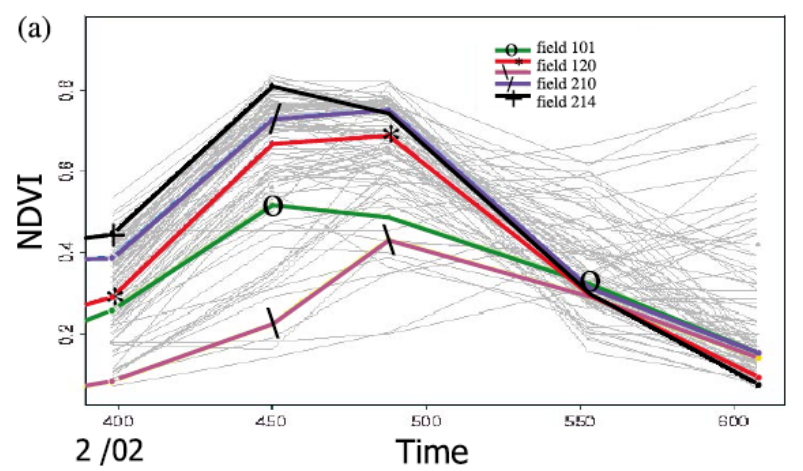

(b)

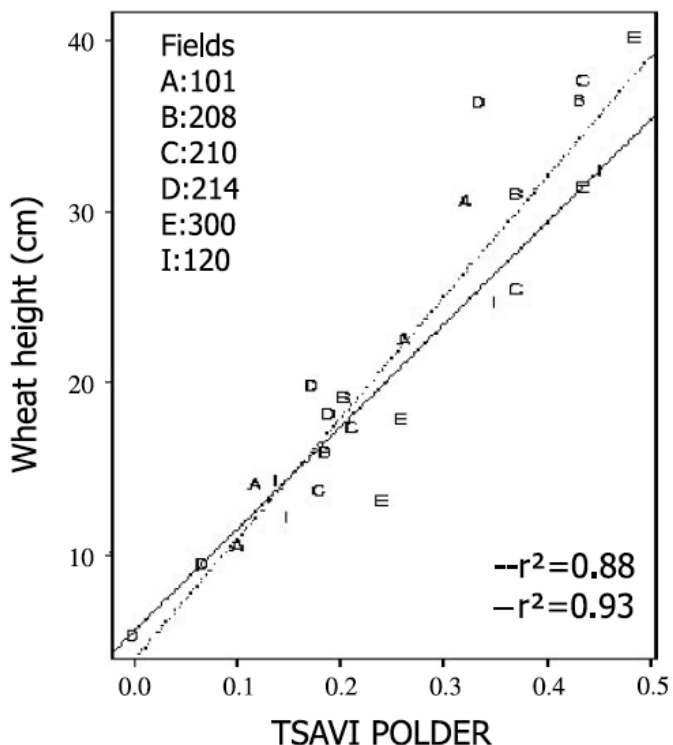

Figure 2. (a) Evolution of the normalized difference vegetation index (NDVI) computed from SPOT images for the 91 wheat fields from February to October. Measurements were done on some fields. Field 214 is spring wheat, field 120 is irrigated wheat, and all others are winter wheat sown at different times. (b) Relationship between the TSAVI index computed from POLDER images and wheat heights measured over the different fields from November 1996 to April 1997. The two lines represent two different models of linear regression: the broken line is based on the least squares fitting method (Isfit), and the solid line is based on the least median of squared residuals method of $y$ on $x$ (Imsreg).

The model also required information about the orography and soil texture. A digital elevation model with a spatial resolution of $75 \mathrm{~m}$ provided orography. Only a small area in the southeast part of the studied region presented some relief (up to $60 \mathrm{~m}$ ). Comparisons have been made between simulations considering orography and without relief for different atmospheric conditions. The results were similar, and therefore we decided to consider the area completely flat $(z=0)$, simplifying the computations.

Soil texture was computed as the average of measurements over sand and clay fractions performed on some fields. We considered the dominant percentage on the whole soil profile, and the values were $4 \%$ for the sand fraction and $40 \%$ for the clay fraction. The main parameters provided to Meso-NH are presented in Table 2. 
Table 2. Surface parameters.

\begin{tabular}{|c|c|}
\hline Parameter & Source \\
\hline \multicolumn{2}{|l|}{ Computed } \\
\hline Vegetation fraction (veg) & \multirow{3}{*}{$\begin{array}{l}\text { Two-dimensional maps } \\
\text { from remote sensing } \\
\text { (POLDER airborne) }\end{array}$} \\
\hline Leaf area index (LAI) & \\
\hline Visible albedo $\left(\alpha_{\mathrm{vis}}\right)$ & \\
\hline Near-infrared albedo $\left(\alpha_{\text {nir }}\right)$ & \multirow{3}{*}{$\begin{array}{l}\text { From land-use map (SPOT } \\
\text { classification) }\end{array}$} \\
\hline Roughness length $\left(z_{0 \mathrm{veg}}\right)$ & \\
\hline Thermal roughness length $\left(z_{0 \mathrm{vegh}}\right)$ & \\
\hline \multicolumn{2}{|l|}{ Estimated } \\
\hline \multicolumn{2}{|l|}{ Emissivity $(\varepsilon)$} \\
\hline \multicolumn{2}{|l|}{ Root depth $\left(d_{2}\right)$} \\
\hline \multicolumn{2}{|l|}{ Linked to stomatal resistance } \\
\hline \multicolumn{2}{|l|}{ Minimal stomatal resistance $\left(r_{\text {smin }}\right)$} \\
\hline \multicolumn{2}{|l|}{ Species-dependent parameter $(\gamma)$} \\
\hline \multicolumn{2}{|l|}{$\begin{array}{l}\text { Parameter linked to stomatal } \\
\text { resistance }\left(r_{\mathrm{gl}}\right)\end{array}$} \\
\hline \multicolumn{2}{|l|}{ Vegetation heat capacity $\left(C_{\mathrm{v}}\right)$} \\
\hline \multicolumn{2}{|l|}{ Soil texture } \\
\hline Clay & Constant values for all the \\
\hline Sand & $\begin{array}{l}\text { area estimated from the } \\
\text { measurement average }\end{array}$ \\
\hline
\end{tabular}

We simulated short periods of $2 \mathrm{~h}$ (or $4 \mathrm{~h}$ ) from 1000 to 1200 hours (or 1400 hours) for different contrasted days (Table 3), with a time step of $1 \mathrm{~s}$, on a supercomputer (NEC SX 5 ) at the Institut du Développement des Ressources en Informatique Scientifique (IDRIS), Centre national de la recherche scientifique (CNRS), Orsay, France The chosen turbulence model was that of Deardorff (1978) (Large Eddy Simulation or LES mode 3D), which means that all the turbulent fluxes were computed. This is necessary for small horizontal meshes; the mixing length is given by the mesh size depending on the model dimensionality. The simulation lasted almost $2 \mathrm{~h}$ (central processing unit time).

\section{Simulation configuration of a homogeneous area with averaging of surface parameters}

To really judge the impact of the finer scale run, we have done a simulation considering the average of all surface parameters given in Table 2 . The averaging method was arithmetic for most of the parameters (or according to 1/log, for roughness), following the method described in Noilhan et al. (1991). The whole area (always with $100 \sim 100 \sim 31$ grid meshes) was then considered as a homogeneous area. The boundary and initial conditions were the same as those used previously for the heterogeneous area. We have just introduced a white noise of $\pm 0.5^{\circ} \mathrm{C}$ to the temperature at the surface. This perturbation was added at random to the dry potential temperature field at the first mass level near the ground. It was used in LES initialisations. Only one date has been analyzed (18 April) for this comparison because of the lengthy computing time. 


\section{Period studied}

Four days were analyzed corresponding to different atmospheric conditions for two development stages of the vegetation. These periods were also chosen because radiosoundings were available every $2 \mathrm{~h}$ for 4 days (16-18 April and 10-12 June).

In April (first period studied), the winter wheat was well developed; since the sunflower or corn had just been sown, some fields were like bare soil. Spring in 1997 was particularly dry, with a long period without precipitation, so the surfaces were very dry, except for the alfalfa or irrigated meadows, which were always supplied with water. Most of the crops did not have a high LAl or biomass ( $\mathrm{LAI}<2$ ). In June (second period studied), the wheat was dry just before the harvest. The sunflower fields were very heterogeneous; because they were not irrigated, they suffered from water stress as a result of the dry spring. The alfalfa and irrigated meadows were still green because of their deep roots. The main characteristics of the 4 days studied are summarized in Table 3. Two days had strong winds ( 16 April and 10 June). The water and thermal contrasts between the different fields were at a maximum on 18 April. Moreover, this date experienced the clearest atmospheric conditions, with no clouds. There were some cloudy periods during the 2 days studied in June, which is why we focus on the results obtained for 18 April. Figure 3 shows the temperature and wind profiles measured over the site with radiosoundings for the 4 days. Because the boundary conditions were defined as cyclic, the initial atmospheric conditions passed through the area for around one and half hours when the wind speed was low $(1 \mathrm{~m} / \mathrm{s})$. Moreover, the surface conditions surrounding the simulation area were quite similar to those of the Alpilles site (mainly wheat crops). Thus, we considered that the short simulations performed were representative of the region and that a balance was obtained after $2 \mathrm{~h}$ of simulation. This does not mean that the state variables did not evolve for $2 \mathrm{~h}$; we illustrate the changes observed from the initial state for fluxes, temperatures, and soil moisture in the Results.

Table 3. Main characteristics of the 4 days simulated with Meso- $\mathrm{NH}$.

\begin{tabular}{lllllll} 
Date & General characteristics & $\begin{array}{l}T_{2} \\
\left({ }^{\circ} \mathrm{C}\right)\end{array}$ & $\begin{array}{l}V_{\mathrm{a}} \\
(\mathrm{m} / \mathrm{s})\end{array}$ & \multicolumn{1}{c}{$\begin{array}{l}\text { Dir } \\
\left({ }^{\circ}\right)\end{array}$} & \multicolumn{1}{l}{$\begin{array}{l}R_{\mathrm{g}} \\
\left(\mathrm{W} / \mathrm{m}^{2}\right)\end{array}$} & $\begin{array}{l}w_{\mathrm{g} 1}-w_{\mathrm{g} 2} \\
\left(\mathrm{~m}^{3} / \mathrm{m}^{3}\right)\end{array}$ \\
\hline 16 April & Sunny; very high wind from north (mistral) & 15.0 & 6.0 & 360 & 835 & $0.26-0.30$ \\
18 April & Sunny; low wind & 15.0 & 2.0 & 30 & 805 & $0.15-0.30$ \\
10 April & Windy; some cloud & 27.9 & 1.5 & 250 & 623 & $0.22-0.28$ \\
12 June & Some cloud; low wind & 26.7 & 1.2 & 340 & 812 & $0.23-0.28$ \\
\hline
\end{tabular}

Note: Dir, wind direction; $R_{\mathrm{g}}$, global radiation; $T_{2}$ and $V_{\mathrm{a}}$, air temperature and horizontal wind speed measured $2 \mathrm{~m}$ above the surface at 1000 hours in the middle of the site on bare soil; $w_{\mathrm{g} 1}$ and $w_{\mathrm{g} 2}$, surface $(0.5 \mathrm{~cm})$ and deep $(0-2 \mathrm{~m})$ soil volumetric water content. 

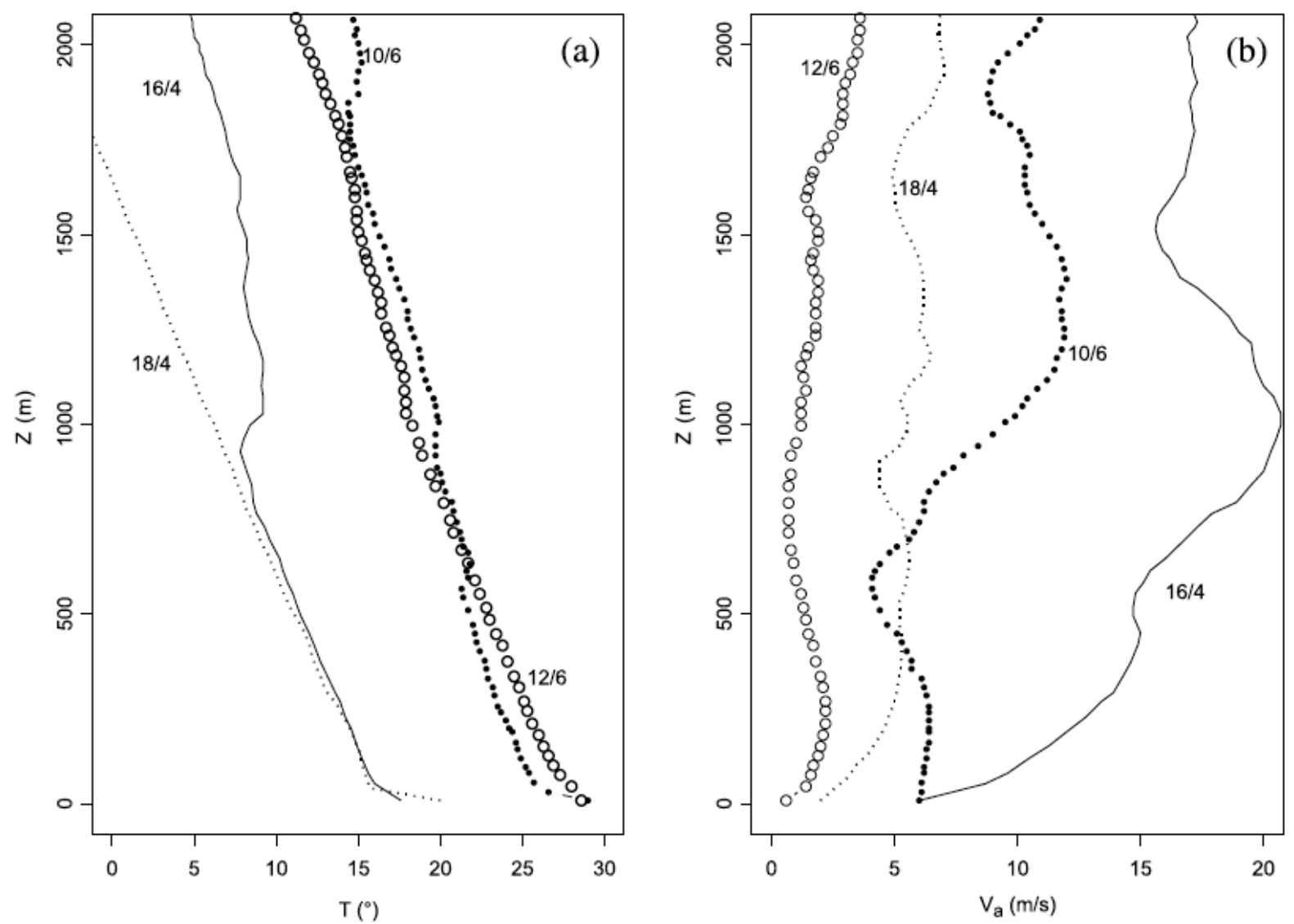

Figure 3. Radiosoundings performed by the CNRM over the Alpilles site at 1000 hours for the 4 days simulated ( 16 and 18 April, 10 and 12 June): (a) temperature profiles, and (b) wind speed profiles.

\section{Results}

Among the different outputs, Meso-NH simulates the evolution of the main variables such as temperature, relative humidity, and wind speed from the surface to the last atmospheric level defined. Table 4 presents the changes in some of these variables from the initial state at 1000 to 1200 hours. A classical increase of air temperature and global radiation was observed from 1000 to 1200 hours, higher for clear and sunny days than for windy and cloudy days, as expected. Differences in relative humidity were more important in June than in April, because of the wetter atmospheric conditions, and so the vegetation developments were very well contrasted. Two-dimensional horizontal or vertical maps can be obtained at each time step for each simulated variable. Figures $4 a$ and $4 \mathrm{~b}$ show the maps of air temperature estimated at 2 and $100 \mathrm{~m}$ above the surface at 1200 hours. Even over a small area, the spatial variability of temperature was great (more than $5{ }^{\circ} \mathrm{C}$ for temperature $2 \mathrm{~m}$ above the ground surface for the whole region). These variations were essentially because of the differences in soil moisture and various crop types. At $2 \mathrm{~m}$ above the surface, the different field patterns could still be recognized, which showed that the main surface characteristics strongly influenced the air above (wind speed being low). At $100 \mathrm{~m}$ above the surface, however, air temperature was more homogeneous, with variations of around $3^{\circ} \mathrm{C}$ over the whole area. It should be noted, however, that these variations corresponded to estimated instantaneous values, which were usually higher than hourly values. 
(a)

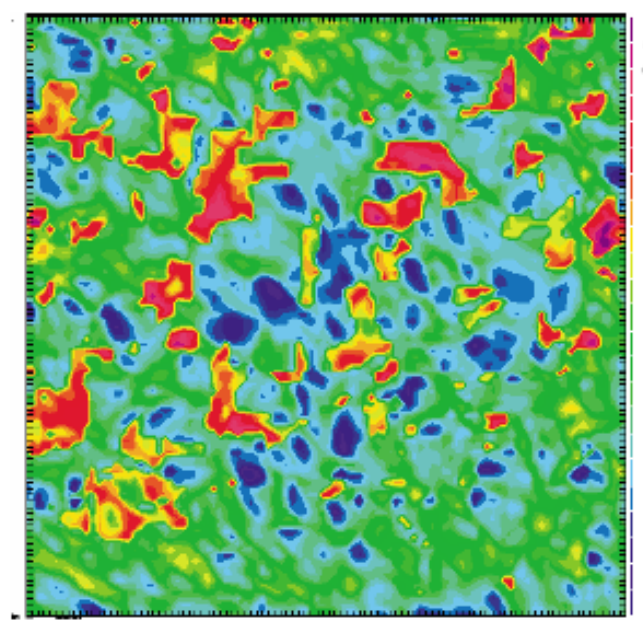

(c)

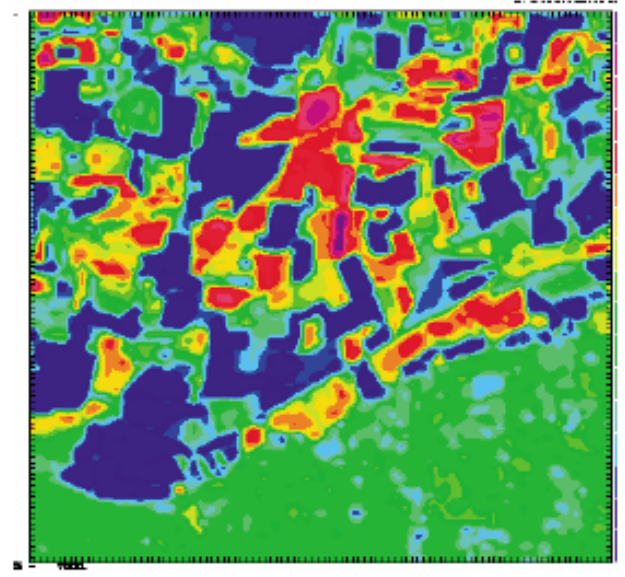

(e)

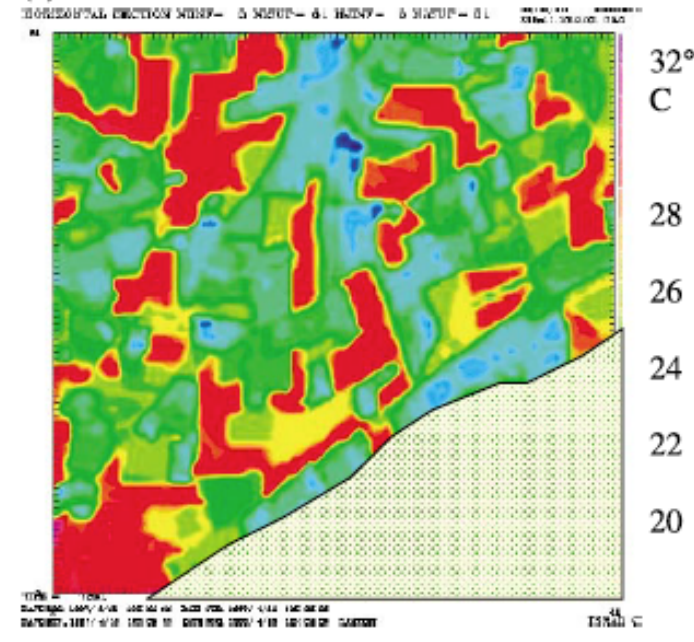

(b)

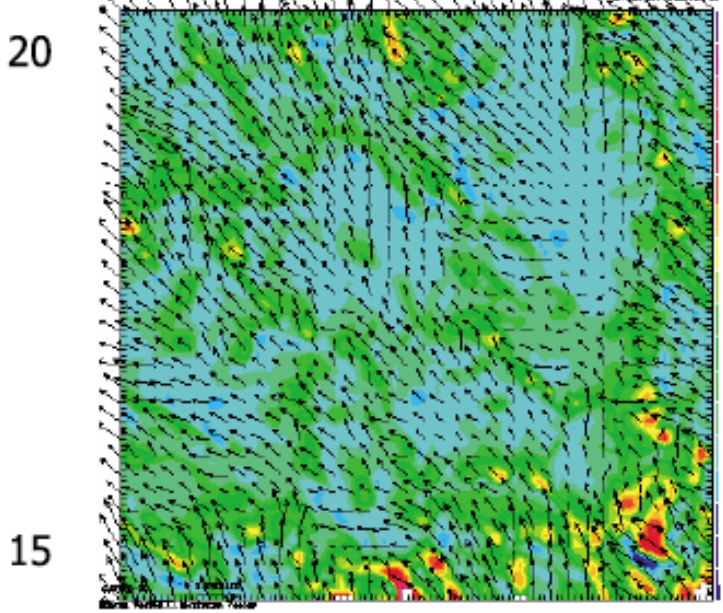

\section{6}

13

(d)
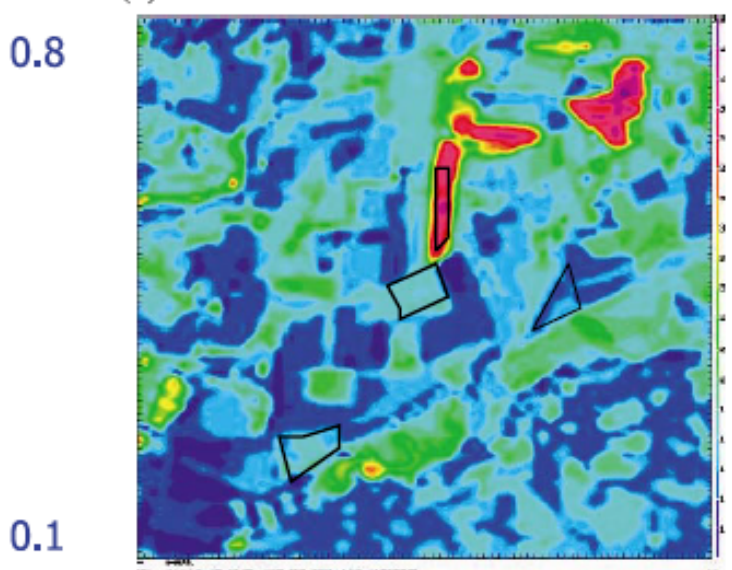

420

$\mathrm{W} / \mathrm{m}^{2}$

100

(f)

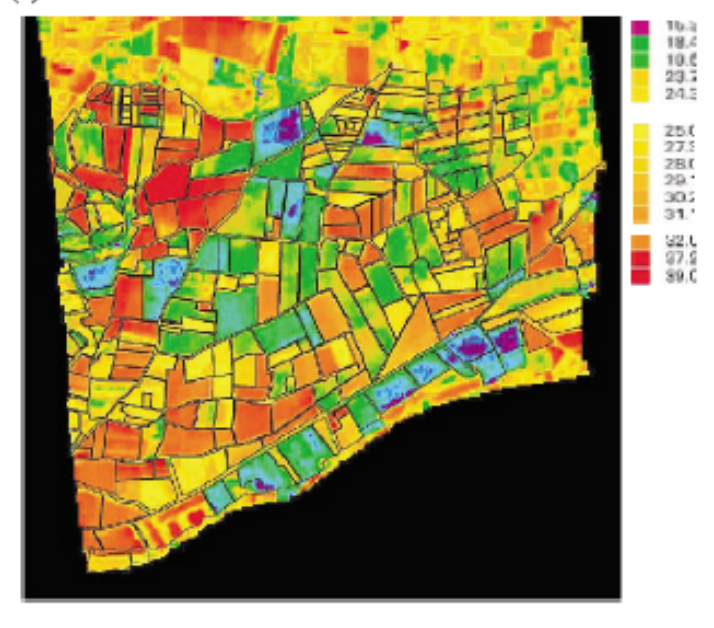

Figure 4. Air temperature $\left({ }^{\circ} \mathrm{C}\right)$ simulated with Meso-NH at 1200 hours on 18 April: (a) $2 \mathrm{~m}$ above the surface, and (b) $100 \mathrm{~m}$ above the surface. Values are instantaneous, with low temperatures in blue and high temperatures in red. The arrows indicate wind direction. (c) Map of vegetation fraction (parameter veg computed from POLDER images) provided as input data for the Meso-NH model. (d) Map of latent heat flux (LE) obtained with Meso-NH (hourly average at 1200 hours on 18 April). (e) Surface temperature simulated with Meso-NH at 1200 hours (the size of the grid mesh is $50 \mathrm{~m}$ ). (f) Surface temperature $\left({ }^{\circ} \mathrm{C}\right.$ ) obtained with a thermal infrared airborne camera (pixel size is $20 \mathrm{~m}$ ). 
Table 4. Changes of some of the main variables from 1000 to 1200 hours.

\begin{tabular}{lllll} 
Date & $T_{2}\left({ }^{\circ} \mathrm{C}\right)$ & $V_{\mathrm{a}}(\mathrm{m} / \mathrm{s})$ & $H_{\mathrm{R}}(\%)$ & $R_{\mathrm{g}}\left(\mathrm{W} / \mathrm{m}^{2}\right)$ \\
\hline 16 April & $15.0-17.7$ & $6.0-7.9$ & $26-18$ & $835-915$ \\
18 April & $15.0-18.0$ & $2.0-1.6$ & $34-19$ & $805-888$ \\
10 April & $27.9-28.9$ & $1.5-3.2$ & $55-52$ & $623-700$ \\
12 June & $26.7-30.7$ & $1.6-1.2$ & $55-39$ & $812-850$
\end{tabular}

When working at a fine scale, all turbulence fluxes were computed (LES mode). The 3D model was then used to analyze these turbulence phenomena linked to the surface characteristics. The spatial variations of the air temperature appeared well correlated with vertical wind speed variations at each atmospheric level. A vertical transect of the atmosphere, in the middle of the studied area, showed coherent structures in the layer between $150 \mathrm{~m}$ and $1500-$ $2000 \mathrm{~m}$ (Figure 5). Alternatively positive and negative wind speeds were observed, forming small convective cells. This phenomenon was observed for all the dates studied, and in another simulation performed by $\mathrm{P}$. Lacarrère (personal communication) for an idealized case in Florida, where a temperature perturbation had been introduced on a homogeneous surface. These structures were observed even for windy conditions ( 16 April). The cell size seemed to be linked to the different surface states (essentially the roughness). Other simulations must be performed for different atmospheric and surface conditions to better understand the formation of these cells. It is particularly important to test the effect of the boundary conditions and the dimensions of the test area on cell size ( $1 \mathrm{~km}$ found here for our example). Much work is currently being done on this subject. 


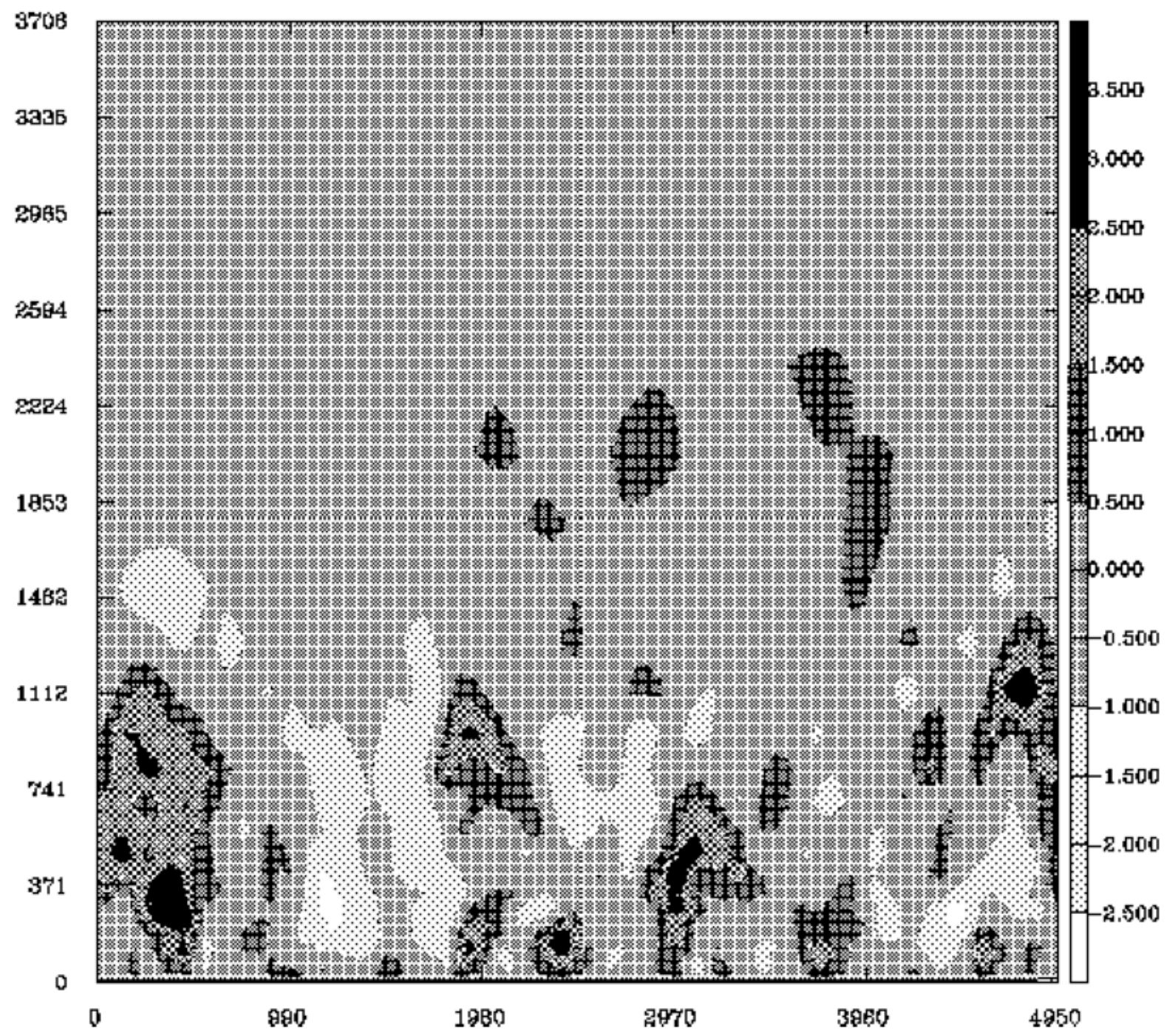

Figure 5. Vertical transect of vertical wind speed simulated at 1200 hours on 18 April from the surface to 4000 $\mathrm{m}$ above the ground, corresponding to the middle of the simulated area. Light gray indicates negative wind speeds ( $\min .-2 \mathrm{~m} / \mathrm{s}$ ), and dark gray indicates high wind speeds ( $>1 \mathrm{~m} / \mathrm{s}$, with max. $3 \mathrm{~m} / \mathrm{s}$ ). The horizontal axis corresponds to $5 \mathrm{~km}$.

\section{Validation of fluxes and surface temperature}

Other interesting outputs were the maps of surface fluxes. A first stage was to validate the estimations comparing the results with the measurements made on several fields (wheat, alfalfa, and sunflower). Table 5 presents the mean differences obtained for the energy fluxes and surface temperature. Figure 6 shows the correlations obtained between measurements and simulations for several fields. For the net radiation, the results were globally satisfactory, except for some fields in June. These fields, primarily sunflower, were very heterogeneous during this period and included areas with well-developed plants and other areas of bare soil. This was due to water stress in the spring. No irrigation was employed, so development was very low. Consequently, measurements were also debatable and may not be representative of the field. Atmospheric conditions may also help to explain the scattering, particularly in June, which experienced cloudy spells that were not simulated by the model. 
Table 5. Mean differences between simulations and measurements (hourly average) computed for several fields.

\begin{tabular}{llllll} 
Date & $\begin{array}{l}R_{\mathrm{n}} \\
\left(\mathrm{W} / \mathrm{m}^{2}\right)\end{array}$ & $\begin{array}{l}H \\
\left(\mathrm{~W} / \mathrm{m}^{2}\right)\end{array}$ & $\begin{array}{l}L E \\
\left(\mathrm{~W} / \mathrm{m}^{2}\right)\end{array}$ & $\begin{array}{l}G \\
\left(\mathrm{~W} / \mathrm{m}^{2}\right)\end{array}$ & $\begin{array}{l}T_{\mathrm{s}} \\
\left({ }^{\circ} \mathrm{C}\right)\end{array}$ \\
\hline 16 April & -15 & -59.0 & 63 & -19.0 & 0.9 \\
18 April & -25 & 0.6 & -8 & -17.6 & 3.0 \\
12 June & 8 & 44.0 & -19 & -17.0 & 0.9 \\
\hline
\end{tabular}

Note: Different methods were used (including Bowen, Eddy correlation) on wheat (fields 101, 120, and 214), sunflower (fields 102 and 501), and alfalfa (field 203). The average of all the field pixels was considered for the simulations.
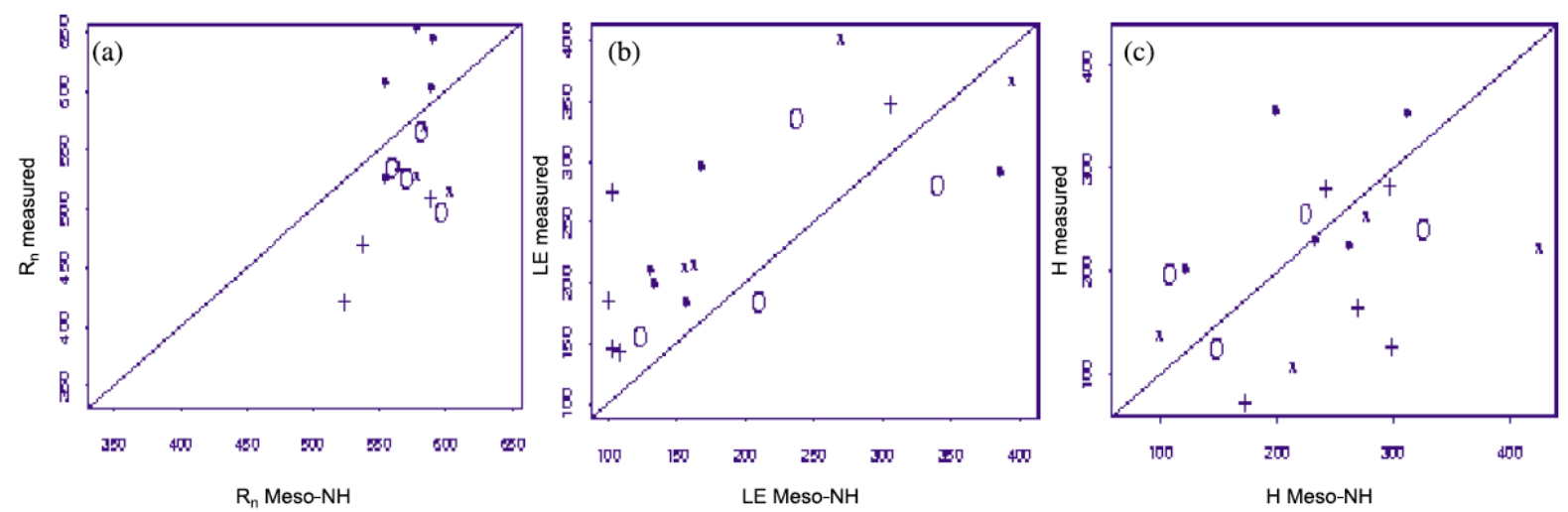

Figure 6. Comparison between measured (Bowen ratio) and Meso-NH-simulated main energy fluxes for several fields in the Alpilles area for 16 April (*), 18 April (o), and 12 June (+) (in W/m2): (a) net radiation Rn; (b) latent heat flux $L E ;$ and (c) sensible heat flux $\mathrm{H}$.

For the convective fluxes ( $\mathrm{H}$ and $\mathrm{LE}$ ), we observed greater dispersion, variable according to the dates. The best correlation was for 18 April, a very sunny day with a low wind speed. For the other dates, the discrepancies between simulations and measurements can be explained by different factors. First, the intrafield heterogeneity was important (comparison was made considering the average of all pixels extracted for each field). This heterogeneity was because of the soil moisture differences, soil texture, and vegetation development. A part of this surface heterogeneity has been introduced in the model with the input parameters (see, for example, the parameter veg, corresponding to the vegetation fraction computed from POLDER images, in Figure $4 \mathrm{c}$ ). On the other hand, an important part of heterogeneity due to the different moisture states of the fields was not well accounted for in our simulations because of the initialization of the soil water content. Indeed, we have fixed constant values for surface (wg1) and deep (wg2) water reserves at to, corresponding to the average of the measurements; however, the fields presented large variations, as shown in Table 6 . Runs being short $(2 \mathrm{~h})$, the soil moisture variations were not significant, and this could explain the overestimations or underestimations observed for latent heat flux simulated with Meso-NH (Figures $6,4 \mathrm{~d}$ ). If we want to improve these results, it is necessary to enter the initial soil moisture variations for future simulations. Until now, such maps were not available for the dates studied. An alternative consists of combining measurements for some fields and estimations for the others. Work is in progress on this point. In addition, simulations with the ISBA scheme (2D version without the atmospheric boundary layer) can be performed for the crop cycle. Soil water contents wg1 and wg2 are then extracted for each crop type for the studied dates. Although this approach seems interesting, particularly in terms of the 
computing time, it requires the temporal interpolation of all surface parameters (presented in Table 2) for the whole area that has not yet been done and may be difficult.

Table 6. Volumetric water content for surface (wg1) and deep (wg2) soil on April 18 from measurements performed on several fields.

\begin{tabular}{llllll} 
& $\begin{array}{l}\text { Wheat, } \\
\text { field 101 }\end{array}$ & $\begin{array}{l}\text { Wheat, } \\
\text { field 120 }\end{array}$ & $\begin{array}{l}\text { Wheat, } \\
\text { field 214 }\end{array}$ & $\begin{array}{l}\text { Alfalfa, } \\
\text { field 203 }\end{array}$ & $\begin{array}{l}\text { Sunflower, } \\
\text { field 501 }\end{array}$ \\
\hline$w_{\mathrm{g} 1}$ & 0.15 & 0.23 & 0.18 & 0.15 & 0.15 \\
$w_{\mathrm{g} 2}$ & 0.28 & 0.35 & 0.33 & 0.23 & 0.31
\end{tabular}

Despite these initialization problems, the maps obtained for the energy fluxes showed great spatial variations, which correctly reproduced the behaviour of the different types of crops. Figure $4 \mathrm{~d}$ shows the latent heat flux map (average value for $1 \mathrm{~h}$ at 1200 hours) obtained for the whole area with Meso-NH for 18 April. The highest value (300 W/m2) corresponds to the irrigated grass or alfalfa, which were well supplied with water, whereas the lowest value (100 $\mathrm{W} / \mathrm{m} 2$ ) corresponds to the sunflower and corn fields. The wheat fields had values from 150 to $200 \mathrm{~W} / \mathrm{m} 2$, thus reflecting the great variations observed due to the various cultural practices (various sowing dates, irrigation).

The Meso-NH-simulated temperatures (Ts) were then compared with remotely sensed temperatures acquired with the INFRAMETRICS 760 airborne thermal infrared camera (Figures $4 \mathrm{e}$ and $4 \mathrm{f}$ ). We observed good agreement for both the highest values (in red, corresponding to bare soils or sunflower crops at the beginning of the cycle) and the lowest values (in blue, corresponding to irrigated grass and alfalfa). The maximum variation of surface temperature was more than $10^{\circ} \mathrm{C}$ over the whole site, which could appear very large in spring. Nevertheless, the soil surface was dry over many of the fields because there was no rainfall for several weeks. Only the crops with deep roots to extract water from the soil did not suffer from water stress.

The comparison of the temperature profile at 1200 hours simulated by the model with the radiosounding performed in the middle of the area at midday showed good agreement (Figure 7) and gave the same level for the atmospheric boundary layer (around $2000 \mathrm{~m}$ ). A small difference of less than $1.5^{\circ} \mathrm{C}$ was observed for the first level near the surface, and this could be explained by the location difference between the points taken for the radiosounding and the Meso-NH outputs at the centre of the mesh. 


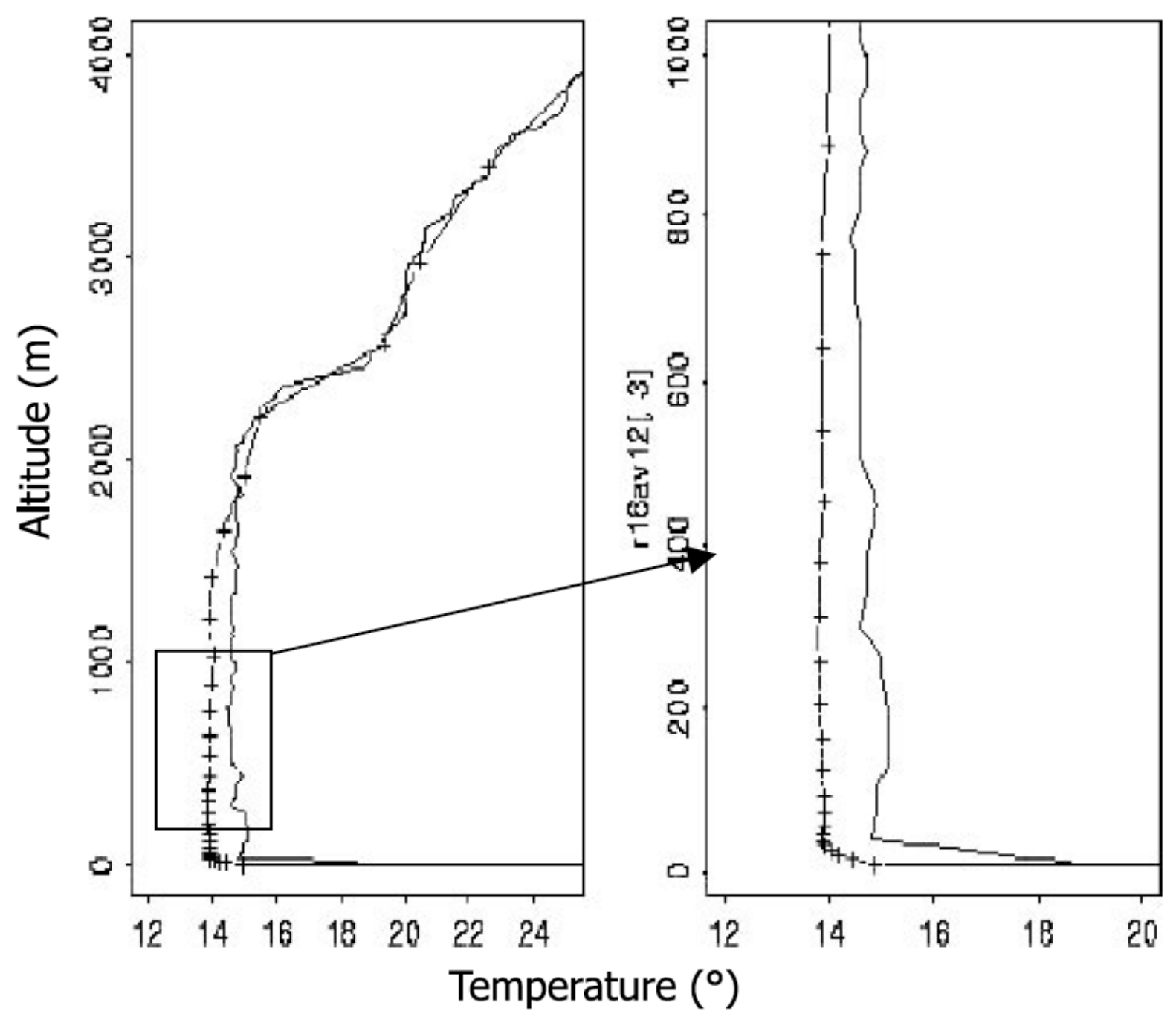

Figure 7. Comparison of the temperature profile estimated by Meso-NH (solid line) with radiosounding measurements (+) taken at 1200 hours in the centre of the study area.

\section{Comparison between averaged and spatialized surface parameters}

We compared the average fluxes with the fluxes calculated using average surface parameters for the whole Alpilles area. For the average surface parameters, the area was considered as homogeneous. Table 7 gives a summary of the statistics obtained for the main energy fluxes and for air temperature estimated at $2 \mathrm{~m}$ above the surface. Significant discrepancies were observed, demonstrating the nonlinearity of the processes. The average of environmental variables from microscale $(50 \mathrm{~m})$ to mesoscale $(5 \mathrm{~km})$ led to differences, which have already been observed by other authors. This is not discussed further in this paper because it was not the main subject of our work and would require more development. We have done only one simulation for 18 April to illustrate the impact of the finer scale compared with coarse resolution and found significant discrepancies. Other simulations for different surface and atmospheric conditions would be necessary to better analyze this scale problem. In particular, the method of averaging surface parameters can also be debated. Different approaches can be found in the literature and should be tested, but this is a concern for future work. 
Table 7. Comparison of fluxes and air temperature ( $2 \mathrm{~m}$ above the surface) estimated for the whole Alpilles area at 1200 hours on 18 April between the homogeneous area with parameters averaged and the real case of a heterogeneous area with parameters distributed.

\begin{tabular}{|c|c|c|c|c|c|c|c|c|}
\hline \multicolumn{3}{|c|}{$\underline{R_{\mathrm{n}}\left(\mathrm{W} / \mathrm{m}^{2}\right)}$} & \multicolumn{2}{|c|}{$H\left(\mathrm{~W} / \mathrm{m}^{2}\right)$} & \multicolumn{2}{|c|}{$L E\left(\mathrm{~W} / \mathrm{m}^{2}\right)$} & \multicolumn{2}{|c|}{$T_{2}\left({ }^{\circ} \mathrm{C}\right)$} \\
\hline & $\begin{array}{l}\text { Real } \\
\text { case }\end{array}$ & $\begin{array}{l}\text { Parameters } \\
\text { averaged }\end{array}$ & $\begin{array}{l}\text { Real } \\
\text { case }\end{array}$ & $\begin{array}{l}\text { Parameters } \\
\text { averaged }\end{array}$ & $\begin{array}{l}\text { Real } \\
\text { case }\end{array}$ & $\begin{array}{l}\text { Parameters } \\
\text { averaged }\end{array}$ & $\begin{array}{l}\text { Real } \\
\text { case }\end{array}$ & $\begin{array}{l}\text { Parameters } \\
\text { averaged }\end{array}$ \\
\hline Min. & 392 & 452 & 30 & 184 & 10 & 139 & 27.5 & 26.3 \\
\hline Max. & 656 & 529 & 638 & 215 & 617 & 154 & 31.8 & 26.9 \\
\hline Mean & 597 & 527 & 335 & 199 & 124 & 147 & 29.7 & 26.6 \\
\hline
\end{tabular}

\section{Discussion and conclusions}

Many studies have dealt with the impact of landscape modification such as deforestation or irrigation on climate change. These phenomena have been simulated using $3 \mathrm{D}$ atmospheric models at the continental scale, and the different surfaces were described with a coarse resolution. Our study focussed on the effect of crops on the spatial variability of temperatures and fluxes at a small scale (i.e., an agricultural region of around $25 \mathrm{~km} 2$ ), using for the first time the $3 \mathrm{D}$ model Meso-NH with a grid mesh of $50 \mathrm{~m}$ to better describe the surface exchanges. Even at this small scale, the crop types induced significant variations in both temperature and surface fluxes. The link between type of crops and its effect was well simulated by the model. The high resolution chosen to describe the different crops allowed better simulation of the transfers between soil, plant, and atmosphere by giving more appropriate surface parameters for each type of crop. Remote sensing data at a resolution of $20 \mathrm{~m}$ were also an indispensable tool to provide accurate inputs. Indeed, identification of each crop type was then possible, even for small fields. Moreover, all the surface parameters characterizing the vegetation development have been extracted from these data using efficient methodologies (neural network for LAI and POLDER images for vegetation fraction; Jacob, 1999) or new relationships between vegetation index (TSAVI) and roughness (zoveg). Until now, the main database used in mesoscale models to characterize the different surfaces was at a resolution of $1 \mathrm{~km}$ (e.g., Ecoclimap derived from NOAA classifications; Masson et al., 2003). The temporal evolution of the different surface parameters is then fixed according to the land-use class and climatological area. Consequently, this induces significant discrepancies, all the more important at a fine scale, in our Mediterranean region, since the fields are small and very heterogeneous. The contribution of the fine resolution is evident by providing more realistic lower boundary conditions, improving the numerical simulations of the atmosphere. Moreover, significant discrepancies were observed between mesoscale and microscale owing to the nonlinearity of processes. It is therefore important to describe the surface with the greatest accuracy possible. The main problem is then to do long runs with fine resolution using atmospheric models. Because of the high cost of computing time (on supercomputers), only short simulations can be performed. With the increasing power of computers, this problem may be solved in a few years.

Nevertheless, these simulations provide new information, particularly on the turbulence phenomenon occurring at the surface. The formation of convective cells observed between 150 and $1500 \mathrm{~m}$ is not yet well analyzed and needs further investigation to better understand the influence of surface characteristics and boundary limits. These cells play an important role in all the convective exchanges and in the temperature resulting from energy and mass balances. Each crop type therefore has a particular microclimate, which directly interacts 
with the plant development. It is therefore important to correctly estimate these microclimates according to the different surfaces studied.

Concerning the validation of Meso-NH used for the first time at a very fine resolution, the first results obtained were globally satisfactory. Improvements can be made by taking into account the spatial variability of soil moisture for initialisation. Works are in progress to this end. Because the runs were short, the outputs were obviously linked to the finer inputs: the maps of simulated fluxes showed patterns correlated with those of the surface parameters (albedo and veg), as expected. The observed spatial variations depended mainly on the stage of vegetation development and on the soil moisture. Their large variability over the whole area was well reproduced by the model (for example, differences of more than $200 \mathrm{~W} / \mathrm{m} 2$ were observed in April between sunflower and alfalfa, in accordance with measurements).

The spatial variations of air temperature at $2 \mathrm{~m}$ above the ground were also not negligible (around $2{ }^{\circ} \mathrm{C}$ in April). These temperature variations are significant for crop development and could explain the observed differences in crop yields (Courault and Ruget, 2001). Other simulations must be performed to confirm these first results for various atmospheric and surface conditions.

This type of model is also a useful tool and the only one that allows analysis of the effect of spatial organisation of the crops in the landscape on the fluxes, to predict climatic changes according to pattern or land-use modifications. The contribution of such a $3 D$ atmospheric model to hydrological studies is also important because it provides quantitative information on the spatial variation of the different surface fluxes; this variation needs to be taken into account to obtain accurate water budgets and to improve our knowledge of how the watershed works. Nevertheless, it is not easy to make the link between atmospheric and hydrological models at the small spatial scale, in particular because of the differences in the model time steps. The atmospheric phenomena require a very short time step (for our case it was $1 \mathrm{~s}$, and the computing time was consequently high, $2 \mathrm{~h}$ on a supercomputer to simulate $2 \mathrm{~h}$ ), whereas the time scale for the hydrological models is often much longer ( 1 day) and the water budgets are often estimated for 1 year. It is worth mentioning, however, that recent projects at CNRM and CNRS have dealt with this link between hydrology and the atmosphere. Until now, the exchange was called passive, which means that the ISBA surface scheme was only used to provide more accurate input surface fluxes to hydrological models (for example, for the Rhone valley GEWEX project). When the grid mesh becomes large enough ( $\geq 10 \mathrm{~km}$ ), it will then be possible to increase the time step in atmospheric models and to consider feedbacks between soil, vegetation, and atmosphere. Such approaches should improve the estimations of water budget.

\section{Acknowledgements}

Special thanks to Juan Escobar and to Didier Gazen (LA Toulouse) for their help using Meso$\mathrm{NH}$ on IDRIS supercomputers.

\section{References}

Baret, F., and Guyot, G. 1991. Potentials and limits of vegetation indices for LAI and APAR assessment. Remote Sensing of Environment, Vol. 35, pp. 165-173. 
Barnston, A.G., and Schickeldanz, P.T. 1984. The effect of irrigation on warm season precipitation in the southern Great Plains. Journal of Climate and Applied Meteorology, Vol. 23, No. 6, pp. 865-888.

Bastiaanssen,W.G.M., Menenti, M., Feddes, R.A., and Holtslag, A.A. 1998. A remote sensing surface energy balance algorithm for land (SEBAL). International Journal of Hydrology, Vol. 212-213, No. 1-4, pp. 198-212.

Courault, D., and Ruget, F. 2001. Impact of local climate variability on crop model estimates in the south-east of France. Climate Research, Vol. 18, pp. 195-204.

Deardorff, J.W. 1978. Efficient prediction of ground surface temperature and moisture with inclusion of a layer of vegetation. Journal of Geophysical Research, Vol. 83, No. 20, pp. 18891903.

De Ridder, K., and Gallée, H. 1998. Land surface induced regional climate change in southern Israel. Journal of Applied Meteorology, Vol. 37, pp. 1470-1485.

Jacob, F. 1999. Utilisation de la télédétection courtes longueur d'onde et infrarouge thermique à haute résolution spatiale pour l'estimation des flux d'énergie à l'échelle de la parcelle agricole. Thèse de doctorat, L'Université Paul Sabatier, Toulouse, France.

Jacob, F., Olioso, A.,Weiss, M., Baret, F., and Hautecoeur, O. 2002a. Mapping short-wave albedo of agricultural surfaces using airborne PolDER data. Remote Sensing of Environment, Vol. 8o, pp. 36-46.

Jacob, F., Weiss, M., Olioso, A., and French, A. 2002b. Assessing the narrowband to broadband conversion to estimate visible, near infrared and shortwave apparent albedo from airborne PoIDER data. Agronomie, Vol. 22, pp. 537-546.

Jacquemin, B., and Noilhan, J. 1990. Validation of a land surface parameterization using the HAPEX-MOBILHY dataset. Boundary Layer Meteorology, Vol. 52, pp. 93-134.

Lagouarde, J.P., and Brunet, Y. 1991. Suivi de l'évapotranspiration réelle journalière à partir des données NOAA-AVHRR lors de la campagne HAPEX-MOBILHY. In Mesures Physiques et Signatures en Télédétection, Proceedings of the $5^{\text {th }}$ International Symposium. European Space Agency Publications Division, ESTEC, Noordwijk, The Netherlands. ESP SP 319, pp. 569-572.

Liang, S., Strahler, A.H., and Walthall, C.W. 1999. Retrieval of land surface albedo from satellite observations: a simulation study. Journal of Applied Meteorology, Vol. 38, pp. 712725 .

Manzi, A.O. 1993. Introduction d'un schéma des transferts sol-végétation- atmosphère dans un modèle de circulation générale et application à la simulation de la déforestation amazonienne. Thèse de doctorat, L'Université Paul Sabatier, Toulouse, France. 
Masson, V., Champeaux, J.L., Chauvin, F., Meriguet, C., and Lacaze, R. 2003. A global database of land surface parameters at $1 \mathrm{~km}$ resolution in meteorological and climate models. Journal of Climate, Vol. 1, No. 9, pp. 1261-1282.

Noilhan, J., and Mahfouf, J.F. 1996. The ISBA land surface parameterisation scheme. Global Planetary Change, Vol. 13, pp. 145-159.

Noilhan, J., Lacarrère, P., and Bougeault, P. 1991. An experiment with an advanced parametrization in a mesobeta-scale model. Part III. Comparison with the Hapex Mobilhy dataset. Monthly Weather Review, Vol. 19, No. 10, pp. 2393-2413.

Olioso, A., Braud, I., Chanzy, A., Demarty, J., Ducros, Y., Gaudu, J.-C., Gonzalez-Sosa, E., Lewan, E., Marloie, O., Ottlé, C., Prévot, L., Thony, J.- L., Autret, H., Bethenod, O., Bonnefond, J.-M., Bruguier, N., Buis, J.-P., Calvet, J.-C., Caselles, V., Chauki, H., Coll, C., François, C., Goujet, R., Jongschaap, R., Kerr, Y., King, C., Lagouarde, J.-P., Laurent, J.-P., Lecharpentier, P., McAneney, J., Moulin, S., Rubio, E., Weiss, M., and Wigneron, J.-P. 2002. Monitoring energy and mass transfers during the Alpilles-ReSeDA experiment. Agronomie, Vol. 22, pp. 597-610.

Pielke, R.A. 2001. Influence of the spatial distribution of vegetation and soils on the prediction of cumulus convective rainfall. Reviews of Geophysics, Vol. 39, No. 2, pp. 151-177. Prévot, L., Baret, F., Chanzy, A., et al. 1999. Assimilation of multi-sensor and multi-temporal remote sensing data to monitor vegetation and soil: the Alpilles Reseda project. In IGARSS'98, Proceedings of the International Geoscience and Remote Sensing Symposium, 6-10 July 1998, Seattle, Wash. Edited by T. Stein. IEEE, New York. pp. 17-30.

Segal, M., Avissar, R., McCumber, M.C., and Pielke, R.A. 1988. Evaluation of vegetation effects on the generation and modification of mesoscale circulations. Journal of Atmospheric Sciences, Vol. 45, No. 16, pp. 2269-2292.

Segal, M., Pan, Z., Turner, R.W., and Takle, E.S. 1998. On the potential impact of irrigated areas in North America on summer rainfall caused by largescale systems. Journal of Applied Meteorology, Vol. 37, pp. 325-331.

Verhoef, W. 1984. Light scattering by leaf layers with application to canopy reflectance modeling: the SAIL model. Remote Sensing of Environment, Vol. 16, pp. 125-141.

Walthall, C.L., Norman, J.M., Welles, G., Campbell, G., and Blad, G.L. 1985. Simple equation to approximate the bidirectional reflectance from vegetative canopies and bare soil surfaces. Applied Optics, Vol. 24, pp. 383-387.

Weiss, M., Baret, F., Leroy, M., Hautecoeur, O., Bacour, C., Prévot, L., and Brugier, N. 2002. Validation of Neural Net techniques to estimate canopy biophysical variables from remote sensing data. Agronomie, Vol. 22, pp. 547-553. 